\title{
Status of Heavy Metals in Soils of Assiut as Affected by the Long-Term Use of Sewage Water in Crop Irrigation: Case Study
}

\author{
A. Elgharably", A. Abdel Mageed ${ }^{* *}$ and G. Elgharably* \\ *Department of Soils and Water, Faculty of Agriculture, Assiut \\ University, Assiut and **Department of Soils, Faculty of \\ Agriculture, Al-Azhar University, Assiut, Egypt.
}

\begin{abstract}
CONCERNING soil pollution with heavy metals, a survey study was carried out to evaluate the present status of $\mathrm{Cd}, \mathrm{Ni}, \mathrm{Pb}, \mathrm{Fe}$, $\mathrm{Mn}, \mathrm{Zn}$ and $\mathrm{Cu}$ in agricultural soils near Assiut city. Over 40-50 years, soils were either irrigated with underground, or sewage waste water at six sites, namely El-Madabegh, Mankabad, Ellwan, Bani Hussein, Bani Ghalleb and Gahdam. Thirty six soil profiles were dug and subsamples were taken to determine the status of the selected elements using standard methods.

Data of this study indicate that the concentrations of Fe, Mn, Zn, $\mathrm{Cu}, \mathrm{Pb}, \mathrm{Cd}$ and $\mathrm{Ni}$ are present at high levels in the soils irrigated with sewage wastewater relative to that irrigated with underground water. A survey to evaluate metals uptake by the crops under agriculture at the indicated sites is needed, but use of sewage wastewater in irrigation at the indicated sites needs to be justified.
\end{abstract}

With increasing global population, the gap between the supply and demand of water is widening and is reaching such alarming levels that in some parts of the world it is posing a threat to human existence. It is therefore of utmost decosystem services. This could release clean water purposes needing fresh water.

Sewage water is an alternative potential source of irrigation water in arid and semiarid areas where fresh water supplies are inadequate. Disposal of sewage waters on sandy soils, especially desert soils that are low in fertility may be beneficial due to its content of nutritious elements and can result in improvement of soil properties.

It is therefore of utmost importance to define new ways of conserving water such as re-use of urban wastewater in agricultural and of these soils to become good media for plant growth (Chaney, 1985, El-Desoky and Gameh, 1998, Badawy and Helal, 2002 and Yadav et al., 2002). However, one of the most limiting factors for land disposal and agricultural use sewage effluents is the presence of high levels of heavy metals $(\mathrm{Cd}, \mathrm{Ni}, \mathrm{Zn}, \mathrm{Cu}, \mathrm{Co}, \mathrm{Cr}$ and $\mathrm{Pb}$ ) which may be toxic to the living organisms. An excessive load of heavy metals can increase both potential phytotoxicity and ground water contamination (Sterritt

E-mail of the corresponding author: age@au.edu.eg 
and Lester, 1980, Emmerich et al., 1982 and Chaney, 1983). Although levels of heavy metals in sewage effluents are low, the long term application of wastewater on agricultural lands often results in the accumulation of elevated levels of these metals in the soils, but this depends upon the period of its application (Ratten et al., 2005). Badawy and Helal (2002) studied the chemical composition of the sewage effluent of Helwan drainage station. They found that the metals can be arranged in the following order: $\mathrm{Fe}>\mathrm{Zn}>\mathrm{Pb}>\mathrm{Mn}>\mathrm{Ni}>$ $\mathrm{Cr}>\mathrm{Co}>\mathrm{Cd}>\mathrm{Cu}$. They also reported that continuous irrigation with sewage effluent, with or without annual addition of sludge lead to: 1) decreasing soil $\mathrm{pH}$ and total carbonate content, 2) increasing organic carbon, clay and available $\mathrm{P}$ and $\mathrm{K}$, and 3 ) increasing contents of heavy metals to be as big as $280-590 \%$ of the initial content after a period of four years. According to Abdel-Sabour et al. (1996), five heavy metals ( $\mathrm{Fe}, \mathrm{Zn}, \mathrm{Cu}, \mathrm{Co}$ and $\mathrm{Pb}$ ) contents were investigated in Cairo sewage effluent being used in irrigation of sandy soil of El-Gabal Al-Asfar Farm. Data reveal that large amounts of $\mathrm{Fe}, \mathrm{Zn}, \mathrm{Cu}$ and $\mathrm{Pb}$ have accumulated over 52 years of irrigation.

The present study aims to evaluate the magnitude of soil contamination with heavy metals resulting from use of sewage wastewater in irrigation of agricultural soils near Assiut city.

\section{Material and Methods}

\section{Study area}

In Assiut City, municipal wastewater from different sources is collected at El-Madabegh village, which lies $8 \mathrm{~km}$ northwest of Assiut City. For many years, without any pretreatment the wastewaters have been applied, through irrigation, to a large agricultural area (8000-10000 feddan). The area has very limited natural water resources without any annual rainfall. Thirty-six soil profiles were dug at different sites in six villages El-Madabeg, Mankabad, Bani Huessein, Bani Ghaleb, Ellwan and Gahdam. The profiles were dug in agricultural areas that have been irrigated with underground, or sewage water.

From each site, several sub-samples from 0-15 and 15-30 cm depths were separately bulked to give composite samples. The soil was air-dried and sieved to $\sim 2 \mathrm{~mm}$. Particle size distribution was determined following the method described in Chapman and Pratt (1978). Soil pH and electrical conductivity (EC) were measured in 1:2.5 soil-water suspension after $1 \mathrm{hr}$ end-over-end shaking at $25^{\circ} \mathrm{C}$. Soil $(1.0 \mathrm{~g})$ was digested with nitric and perchloric acid mixture (Baker and Amacher, 1982) for measurement of the total concentrations of $\mathrm{Fe}, \mathrm{Mn}, \mathrm{Zn}$, $\mathrm{Cu}, \mathrm{Cd}, \mathrm{Ni}$ and $\mathrm{Pb}$. Soil available $\mathrm{Fe}, \mathrm{Mn}, \mathrm{Zn}, \mathrm{Cu}, \mathrm{Cd} \mathrm{Ni}$ and $\mathrm{Pb}$ were extracted by diethylenetriaminepenta-acetic acid following (Lindsay and Norvell, 1978). The extracted elements were determined using a flame-Atomic Absorption Spectrometer (GBC, 906AA). The total organic matter content was determined and soil $\mathrm{CaCO}_{3}$ was measured using the calcimeter method as mentioned by Chapman and Pratt (1978). The soil physical and chemical properties of the soil irrigated with sewage water (SW) and underground water (UW) are presented in Table 1 and 2, respectively.

Egypt. J. Soil Sci. 54, No. 4 (2014) 
TABLE 1. Physical and chemical parameters of the surface and subsurface layers of the soils irrigated with sewage water (SW).

\begin{tabular}{|c|c|c|c|c|c|c|c|c|c|}
\hline \multirow{2}{*}{ Site } & \multirow{2}{*}{$\begin{array}{l}\text { Depth } \\
(\mathrm{cm})\end{array}$} & \multicolumn{3}{|c|}{$\begin{array}{l}\text { Particle Size } \\
\text { Distribution }\end{array}$} & \multirow{2}{*}{$\begin{array}{c}\text { Soil } \\
\text { Texture }\end{array}$} & \multirow[t]{2}{*}{ O.M. } & \multirow{2}{*}{$\mathrm{CaCO}_{3}$} & \multirow{2}{*}{$\mathbf{p H}_{1: 2.5}$} & \multirow{2}{*}{$\begin{array}{l}\mathbf{E C}_{1: 2.5} \\
\mathbf{d S} \mathbf{~ m}^{-1}\end{array}$} \\
\hline & & Sand & \multicolumn{2}{|c|}{$\begin{array}{l}\text { Silt Clay } \\
\%\end{array}$} & & & & & \\
\hline \multirow[t]{6}{*}{ El-Madabegh } & $0-15$ & 79.8 & 12.0 & 8.2 & LS & $3.7 \pm 0.1$ & $6.1 \pm 0.2$ & $7.38 \pm 0.02$ & $1.94 \pm 0.02$ \\
\hline & $15-30$ & 74.6 & 20.0 & 5.4 & SL & $3.0 \pm 0.2$ & $5.5 \pm 0.1$ & $6.60 \pm 0.01$ & $2.06 \pm 0.01$ \\
\hline & $0-15$ & 84.0 & 8.0 & 8.0 & LS & $4.5 \pm 0.2$ & $8.2 \pm 0.2$ & $7.81 \pm 0.02$ & $1.26 \pm 0.02$ \\
\hline & $15-30$ & 76.1 & 12.1 & 12.8 & SL & $3.2 \pm 0.1$ & $8.2 \pm .0$ & $8.43 \pm 0.02$ & $1.92 \pm 0.01$ \\
\hline & $0-15$ & 71.8 & 20.0 & 8.2 & SL & $2.3 \pm 0.2$ & $10.2 \pm 0.3$ & $7.74 \pm 0.01$ & $3.38 \pm 0.02$ \\
\hline & $15-30$ & 71.8 & 16.0 & 12.2 & SL & $3.3 \pm 0.2$ & $7.5 \pm 0.3$ & $7.74 \pm 0.02$ & $2.73 \pm 0.02$ \\
\hline \multirow[t]{6}{*}{ Mankabad } & $0-15$ & 79.8 & 12.0 & 8.2 & LS & $3.9 \pm 0.1$ & $6.8 \pm 0.4$ & $8.00 \pm 0.01$ & $2.59 \pm 0.01$ \\
\hline & $15-30$ & 75.8 & 12.0 & 12.2 & SL & $3.1 \pm 0.1$ & $6.5 \pm 0.2$ & $8.14 \pm 0.02$ & $2.6 \pm 0.02$ \\
\hline & $0-15$ & 93.5 & 4.0 & 2.50 & $S$ & $2.3 \pm 0.2$ & $5.9 \pm 0.3$ & $8.41 \pm 0.02$ & $1.94 \pm 0.03$ \\
\hline & $15-30$ & 79.8 & 12.0 & 8.2 & LS & $2.3 \pm 0.3$ & $7.9 \pm 0.5$ & $8.49 \pm 0.03$ & $1.83 \pm 0.02$ \\
\hline & $0-15$ & 40.6 & 36.0 & 23.4 & SCL & $4.4 \pm 0.2$ & $9.5 \pm 0.2$ & $8.43 \pm 0.02$ & $2.38 \pm 0.02$ \\
\hline & $15-30$ & 50.6 & 26.0 & 23.4 & SCL & $3.6 \pm 0.3$ & $8.1 \pm 0.3$ & $8.41 \pm 0.02$ & $2.38 \pm 0.03$ \\
\hline \multirow[t]{6}{*}{ Bani Hussein } & $0-15$ & 85.0 & 10.1 & 4.9 & $S$ & $2.0 \pm 0.2$ & $7.3 \pm 0.2$ & $7.02 \pm 0.01$ & $1.65 \pm 0.02$ \\
\hline & $15-30$ & 83.8 & 12.0 & 4.2 & LS & $1.8 \pm 0.2$ & $6.1 \pm 0.2$ & $7.02 \pm 0.02$ & $1.69 \pm 0.02$ \\
\hline & $0-15$ & 72.0 & 20.0 & 8.0 & SL & $3.4 \pm 0.1$ & $6.4 \pm 0.1$ & $7.45 \pm 0.03$ & $2.49 \pm 0.02$ \\
\hline & $15-30$ & 68.0 & 28.0 & 4.0 & SL & $2.3 \pm 0.2$ & $8.3 \pm 0.4$ & $7.45 \pm 0.04$ & $2.15 \pm 0.02$ \\
\hline & $0-15$ & 72.0 & 21.0 & 7.0 & SL & $3.4 \pm 0.2$ & $6.4 \pm 0.2$ & $7.63 \pm 0.01$ & $1.88 \pm 0.02$ \\
\hline & $15-30$ & 68.0 & 26.0 & 6.0 & SL & $2.9 \pm 0.3$ & $8.4 \pm 0.1$ & $7.72 \pm 0.10$ & $1.19 \pm 0.02$ \\
\hline \multirow[t]{6}{*}{ Bani Ghalleb } & $0-15$ & 60.0 & 28.1 & 11.9 & LS & $4.2 \pm 0.2$ & $9.2 \pm 0.2$ & $7.78 \pm 0.01$ & $2.67 \pm 0.02$ \\
\hline & $15-30$ & 63.0 & 16.0 & 21.0 & LS & $3.2 \pm 0.1$ & $7.4 \pm 0.3$ & $7.42 \pm 0.02$ & $2.72 \pm 0.02$ \\
\hline & $0-15$ & 13.0 & 50.0 & 37.0 & SCL & $3.1 \pm 0.3$ & $8.2 \pm 0.1$ & $7.88 \pm 0.03$ & $2.20 \pm 0.02$ \\
\hline & $15-30$ & 46.0 & 36.0 & 18.0 & SCL & $2.2 \pm 0.1$ & $6.7 \pm 0.1$ & $7.56 \pm 0.03$ & $2.29 \pm 0.03$ \\
\hline & $0-15$ & 90.0 & 4.1 & 5.9 & $S$ & $4.5 \pm 0.1$ & $5.9 \pm 0.0$ & $8.21 \pm 0.02$ & $1.89 \pm 0.01$ \\
\hline & $15-30$ & 80.0 & 12.0 & 8.0 & LS & $4.1 \pm 0.1$ & $7.9 \pm 0.3$ & $8.39 \pm 0.02$ & $1.93 \pm 0.01$ \\
\hline \multirow[t]{6}{*}{ Ellwan } & $0-15$ & 46.0 & 32.0 & 22.0 & SCL & $3.2 \pm 0.1$ & $7.8 \pm 0.1$ & $8.00 \pm 0.01$ & $2.29 \pm 0.02$ \\
\hline & $15-30$ & 43.2 & 28.0 & 28.8 & SCL & $2.9 \pm 0.2$ & $7.6 \pm 0.2$ & $8.00 \pm 0.02$ & $2.41 \pm 0.01$ \\
\hline & $0-15$ & 36.2 & 41.3 & 21.5 & SCL & $3.5 \pm 0.2$ & $8.8 \pm 0.1$ & $8.23 \pm 0.01$ & $2.11 \pm 0.01$ \\
\hline & $15-30$ & 41.0 & 40.0 & 19.0 & SCL & $2.4 \pm 0.1$ & $8.6 \pm 0.0$ & $7.88 \pm 0.02$ & $2.30 \pm 0.02$ \\
\hline & $0-15$ & 38.0 & 42.0 & 20.0 & SCL & $4.5 \pm 0.2$ & $10 . \pm 0.3$ & $8.55 \pm 0.03$ & $2.36 \pm 0.01$ \\
\hline & $15-30$ & 35.0 & 44.0 & 21.0 & SCL & $4.2 \pm 0.2$ & $10 . \pm 0.2$ & $8.55 \pm 0.02$ & $2.29 \pm 0.02$ \\
\hline \multirow[t]{6}{*}{ Gahdam } & $0-15$ & 12.8 & 52.0 & 35.2 & SCL & $3.4 \pm 0.2$ & $8.4 \pm 0.1$ & $8.30 \pm 0.01$ & $0.95 \pm 0.02$ \\
\hline & $15-30$ & 47.2 & 28.0 & 24.8 & SCL & $3.2 \pm 0.2$ & $8.3 \pm 0.3$ & $8.30 \pm 0.01$ & $0.83 \pm 0.02$ \\
\hline & $0-15$ & 41.2 & 40.0 & 18.8 & SCL & $4.3 \pm 0.2$ & $8.6 \pm 0.3$ & $7.80 \pm 0.03$ & $1.93 \pm 0.01$ \\
\hline & $15-30$ & 46.2 & 34.0 & 20.8 & SCL & $2.9 \pm 0.2$ & $8.8 \pm 0.2$ & $7.93 \pm 0.03$ & $1.85 \pm 0.02$ \\
\hline & $0-15$ & 37.8 & 42.0 & 20.2 & SCL & $4.1 \pm 0.1$ & $7.1 \pm 0.1$ & $8.02 \pm 0.02$ & $2.10 \pm 0.01$ \\
\hline & $15-30$ & 31.0 & 46.0 & 23.0 & SCL & $3.3 \pm 0.1$ & $6.7 \pm 0.2$ & $8.02 \pm 0.03$ & $1.35 \pm 0.03$ \\
\hline
\end{tabular}


TABLE 2. Physical and chemical parameters of the surface and subsurface layers of the soils irrigated with underground water (UW).

\begin{tabular}{|c|c|c|c|c|c|c|c|c|c|}
\hline \multirow{3}{*}{ Site } & \multirow{3}{*}{$\begin{array}{l}\text { Depth } \\
(\mathrm{cm}) \\
\end{array}$} & \multicolumn{3}{|c|}{$\begin{array}{l}\text { Particle Size } \\
\text { Distribution }\end{array}$} & \multirow{3}{*}{$\begin{array}{c}\text { Soil } \\
\text { Texture }\end{array}$} & \multirow[t]{3}{*}{ O.M. } & \multirow[t]{2}{*}{$\mathrm{CaCO}_{3}$} & \multirow{3}{*}{$\mathbf{p} \mathbf{H}_{1: 2.5}$} & \multirow{3}{*}{ 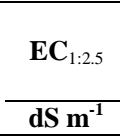 } \\
\hline & & Sand & Silt & Clay & & & & & \\
\hline & & \multicolumn{3}{|c|}{$\%$} & & & $\%$ & & \\
\hline \multirow[t]{6}{*}{ El-Madabegh } & $0-15$ & 29.6 & 24.9 & 45.5 & CL & $3.2 \pm 0.1$ & $6.1 \pm 0.2$ & $7.81 \pm 0.05$ & $0.81 \pm 0.02$ \\
\hline & $15-30$ & 31.5 & 23.8 & 44.7 & $\mathrm{CL}$ & $2.1 \pm 0.1$ & $6.1 \pm 0.2$ & $7.82 \pm 0.02$ & $0.81 \pm 0.03$ \\
\hline & $0-15$ & 29.0 & 25.5 & 45.5 & CL & $2.8 \pm 0.2$ & $5.9 \pm 0.1$ & $7.82 \pm 0.03$ & $0.76 \pm 0.01$ \\
\hline & $15-30$ & 30.9 & 24.4 & 44.7 & $\mathrm{CL}$ & $2.6 \pm 0.1$ & $5.9 \pm 0.1$ & $7.83 \pm 0.02$ & $0.88 \pm 0.01$ \\
\hline & $0-15$ & 28.6 & 25.8 & 45.6 & $\mathrm{CL}$ & $2.5 \pm 0.3$ & $6.6 \pm 0.1$ & $7.84 \pm 0.01$ & $0.90 \pm 0.05$ \\
\hline & $15-30$ & 30.6 & 25.2 & 44.2 & $\mathrm{CL}$ & $2.4 \pm 0.1$ & $6.1 \pm 0.1$ & $7.81 \pm 0.02$ & $1.11 \pm 0.01$ \\
\hline \multirow[t]{6}{*}{ Mankabad } & $0-15$ & 28.4 & 25.3 & 46.3 & CL & $1.1 \pm 0.1$ & $5.1 \pm 0.1$ & $8.02 \pm 0.01$ & $0.57 \pm 0.01$ \\
\hline & $15-30$ & 29.5 & 24.8 & 45.7 & CL & $1.1 \pm 0.1$ & $5.1 \pm 0.1$ & $8.01 \pm 0.02$ & $0.64 \pm 0.02$ \\
\hline & $0-15$ & 29.0 & 25.0 & 46.0 & $\mathrm{CL}$ & $2.2 \pm 0.1$ & $5.3 \pm 0.2$ & $7.91 \pm 0.05$ & $0.50 \pm 0.02$ \\
\hline & $15-30$ & 31.0 & 24.0 & 45.0 & CL & $2.0 \pm 0.2$ & $5.6 \pm 0.2$ & $7.92 \pm 0.02$ & $0.60 \pm 0.03$ \\
\hline & $0-15$ & 29.0 & 24.0 & 47.0 & $\mathrm{CL}$ & $2.2 \pm 0.2$ & $6.1 \pm 0.2$ & $7.82 \pm 0.04$ & $0.80 \pm 0.01$ \\
\hline & $15-30$ & 31.4 & 24.6 & 44.0 & $\mathrm{CL}$ & $2.4 \pm 0.1$ & $6.3 \pm 0.2$ & $7.81 \pm 0.06$ & $1.12 \pm 0.02$ \\
\hline \multirow[t]{6}{*}{ Bani Hussein } & $0-15$ & 22.0 & 49.9 & 28.1 & $\mathrm{~L}$ & $2.0 \pm 0.3$ & $6.1 \pm 0.1$ & $8.12 \pm 0.01$ & $0.61 \pm 0.01$ \\
\hline & $15-30$ & 21.0 & 50.0 & 29.0 & $\mathrm{~L}$ & $1.1 \pm 0.1$ & $6.0 \pm 0.1$ & $8.03 \pm 0.02$ & $0.72 \pm 0.02$ \\
\hline & $0-15$ & 21.4 & 48.8 & 29.3 & $\mathrm{~L}$ & $2.0 \pm 0.3$ & $6.1 \pm 0.2$ & $7.91 \pm 0.02$ & $0.51 \pm 0.02$ \\
\hline & $15-30$ & 21.0 & 49.6 & 29.6 & $\mathrm{~L}$ & $1.6 \pm 0.1$ & $6.0 \pm 0.2$ & $7.92 \pm 0.01$ & $0.63 \pm 0.03$ \\
\hline & $0-15$ & 21.0 & 50.2 & 28.8 & $\mathrm{~L}$ & $2.6 \pm 0.3$ & $6.3 \pm 0.2$ & $7.93 \pm 0.03$ & $0.71 \pm 0.05$ \\
\hline & $15-30$ & 20.0 & 50.0 & 30.0 & $\mathrm{~L}$ & $2.2 \pm 0.1$ & $6.1 \pm 0.1$ & $7.91 \pm 0.04$ & $0.81 \pm 0.01$ \\
\hline \multirow[t]{6}{*}{ Bani Ghalleb } & $0-15$ & 28.0 & 34.3 & 37.7 & $\mathrm{CL}$ & $2.4 \pm 0.2$ & $4.0 \pm 0.2$ & $7.92 \pm 0.01$ & $2.95 \pm 0.05$ \\
\hline & $15-30$ & 11.0 & 45.4 & 43.6 & $\mathrm{~L}$ & $2.0 \pm 0.1$ & $3.3 \pm 0.1$ & $7.91 \pm 0.02$ & $2.91 \pm 0.01$ \\
\hline & $0-15$ & 27.8 & 34.5 & 37.7 & $\mathrm{CL}$ & $2.1 \pm 0.1$ & $3.8 \pm 0.2$ & $7.92 \pm 0.01$ & $1.81 \pm 0.02$ \\
\hline & $15-30$ & 11.5 & 45.0 & 43.5 & $\mathrm{~L}$ & $2.0 \pm 0.2$ & $3.2 \pm 0.2$ & $7.41 \pm 0.03$ & $1.93 \pm 0.01$ \\
\hline & $0-15$ & 27.0 & 34.8 & 38.2 & $\mathrm{CL}$ & $2.5 \pm 0.2$ & $4.1 \pm 0.1$ & $7.91 \pm 0.01$ & $2.81 \pm 0.02$ \\
\hline & $15-30$ & 12.0 & 45.1 & 43.9 & $\mathrm{~L}$ & $2.1 \pm 0.2$ & $3.2 \pm 0.2$ & $7.92 \pm 0.06$ & $2.25 \pm 0.02$ \\
\hline \multirow[t]{6}{*}{ Ellwan } & 0-15 & 25.1 & 35.6 & 39.3 & $\mathrm{~L}$ & $3.1 \pm 0.1$ & $4.3 \pm 0.2$ & $8.03 \pm 0.01$ & $2.14 \pm 0.01$ \\
\hline & $15-30$ & 30.6 & 29.6 & 39.8 & $\mathrm{CL}$ & $2.6 \pm 0.1$ & $3.0 \pm 0.2$ & $8.03 \pm 0.02$ & $2.21 \pm 0.02$ \\
\hline & $0-15$ & 24.8 & 36.2 & 39.0 & $\mathrm{~L}$ & $2.8 \pm 0.1$ & $4.1 \pm 0.2$ & $8.04 \pm 0.01$ & $2.01 \pm 0.02$ \\
\hline & $15-30$ & 31.0 & 29.0 & 40.0 & CL & $2.4 \pm 0.1$ & $3.0 \pm 0.2$ & $8.02 \pm 0.02$ & $2.11 \pm 0.02$ \\
\hline & $0-15$ & 30.5 & 30.6 & 38.9 & $\mathrm{~L}$ & $3.4 \pm 0.1$ & $5.2 \pm 0.2$ & $8.11 \pm 0.02$ & $2.22 \pm 0.02$ \\
\hline & $15-30$ & 31.2 & 30.0 & 39.8 & $\mathrm{CL}$ & $3.3 \pm 0.1$ & $4.2 \pm 0.1$ & $8.02 \pm 0.01$ & $2.42 \pm 0.01$ \\
\hline \multirow[t]{6}{*}{ Gahdam } & $0-15$ & 20.9 & 50.1 & 29.0 & $\mathrm{~L}$ & $2.8 \pm 0.1$ & $3.2 \pm 0.1$ & $7.71 \pm 0.03$ & $1.32 \pm 0.03$ \\
\hline & $15-30$ & 20.8 & 49.2 & 30.0 & $\mathrm{~L}$ & $2.4 \pm 0.2$ & $2.9 \pm 0.1$ & $7.81 \pm 0.01$ & $1.12 \pm 0.01$ \\
\hline & $0-15$ & 21.0 & 50.0 & 29.0 & $\mathrm{~L}$ & $2.6 \pm 0.2$ & $3.0 \pm 0.1$ & $7.82 \pm 0.02$ & $1.33 \pm 0.01$ \\
\hline & $15-30$ & 21.0 & 49.2 & 29.8 & $\mathrm{~L}$ & $2.7 \pm 0.2$ & $3.0 \pm 0.1$ & $7.82 \pm 0.01$ & $1.32 \pm 0.02$ \\
\hline & $0-15$ & 20.0 & 50.0 & 30.0 & $\mathrm{~L}$ & $2.9 \pm 0.2$ & $3.4 \pm 0.1$ & $7.82 \pm 0.01$ & $1.43 \pm 0.01$ \\
\hline & $15-30$ & 21.0 & 49.0 & 40.0 & $\mathrm{~L}$ & $2.6 \pm 0.2$ & $3.0 \pm 0.2$ & $7.83 \pm 0.03$ & $1.11 \pm 0.02$ \\
\hline
\end{tabular}

Values are means $(n=3) \pm S E$

Egypt. J. Soil Sci. 54, No. 4 (2014) 


\section{Water analysis}

It was found necessary to complete this study, being concerned with pollution through irrigation with water to which effluents of sewage water were disposed, by analyzing the wastewater discharged from El-Madabegh sewage. EC and $\mathrm{pH}$ and the total concentrations of $\mathrm{Fe}, \mathrm{Mn}, \mathrm{Zn}, \mathrm{Cu}, \mathrm{Cd}, \mathrm{Ni}$ and $\mathrm{Pb}$ were determined in the sewage water (Table 3).

\section{Statistical analysis}

Data were subjected to analysis of variance using MStat, a micro-computer program. In Tables, values are means $(n=3) \pm$ the standard error $(S E)$. In figure, error bars represent SE.

\section{Results and Discussion}

\section{Total metal concentrations in soils}

Figure 1 shows the variation in total amounts of $\mathrm{Fe}, \mathrm{Mn}, \mathrm{Zn}, \mathrm{Cu}, \mathrm{Cd}, \mathrm{Ni}$ and $\mathrm{Pb}$ in soils of the six locations (villages) of the study area irrigated by untreated sewage wastewater for 45-50 years.

Iron $(\mathrm{Fe})$ : The concentrations of total $\mathrm{Fe}$ in soils of Bani Ghalleb and Gahdam are insignificantly different and were lower than those in the soils of El-Madabegh, Mankabad and Ellwan. The lowest Fe concentration (1316 mg kg${ }^{-1}$ soil) was found in Bani Hussien area and the highest concentration (9475 $\mathrm{mg} \mathrm{kg}^{-1}$ soil) was recorded in soils of Ellwan. The concentration of total Fe in soils of the Alluvial soils near Assiut city, except Bani Hussien, were extremely high compared to that reported by Elsokkary and Lag (1978). El-Demerdashe et al. (1991) and Abd El-Salam (2002) found that the total Fe in Alluvial soils varied from 4997 to $9375 \mathrm{mg} \mathrm{kg}^{-1}$ soil which is in agreement of data reported in this study. The accumulation of total $\mathrm{Fe}$ in these soils decreased in the order: Ellwan > Mankabad > El-Madabegh > Bani Ghalleb > Gahdam > Bani Hussien. It is also clear that the total $\mathrm{Fe}$ in all sites decreased with depth. Similar results were obtained by Shaymaa (2008).

Manganese (Mn): Elsokkary and Lag (1978) reported concentrations of total $\mathrm{Mn}$ as 617 and $645 \mathrm{mg} \mathrm{kg}^{-1}$ soil in alluvial and lacustrine soils. ElDemerdashe et al. (1991) reported values of total Mn in soils of North Tahrir ranged from 90 to $350 \mathrm{mg} \mathrm{kg}^{-1}$ soil in the surface layer and Shahin and Abdel Hamid (1993) found that total Mn contents in calcareous soils of Maryout in the range $186-379 \mathrm{mg} \mathrm{kg}^{-1}$ soil. In this study, there is marked variation in the concentration of total $\mathrm{Mn}$ in soils of the six locations (Fig. 1). The concentration of total $\mathrm{Mn}$ in soil of El-Madabegh area was the lowest (3985.5 mg kg-1 soil), while the highest concentration of is in soils (18513 mg kg-1 soil) of Bani Hussien. The average values were 3985.5, 5735, 9990, 18513, 5403 and 4323 $\mathrm{mg} \mathrm{kg}^{-1}$ soil in El-Madabegh, Mankabad, Ellwan, Bani Hussien, Bani Ghalleb and Gahdam, respectively. Total Mn was decreased with depth in different soil profiles of the studied areas. 


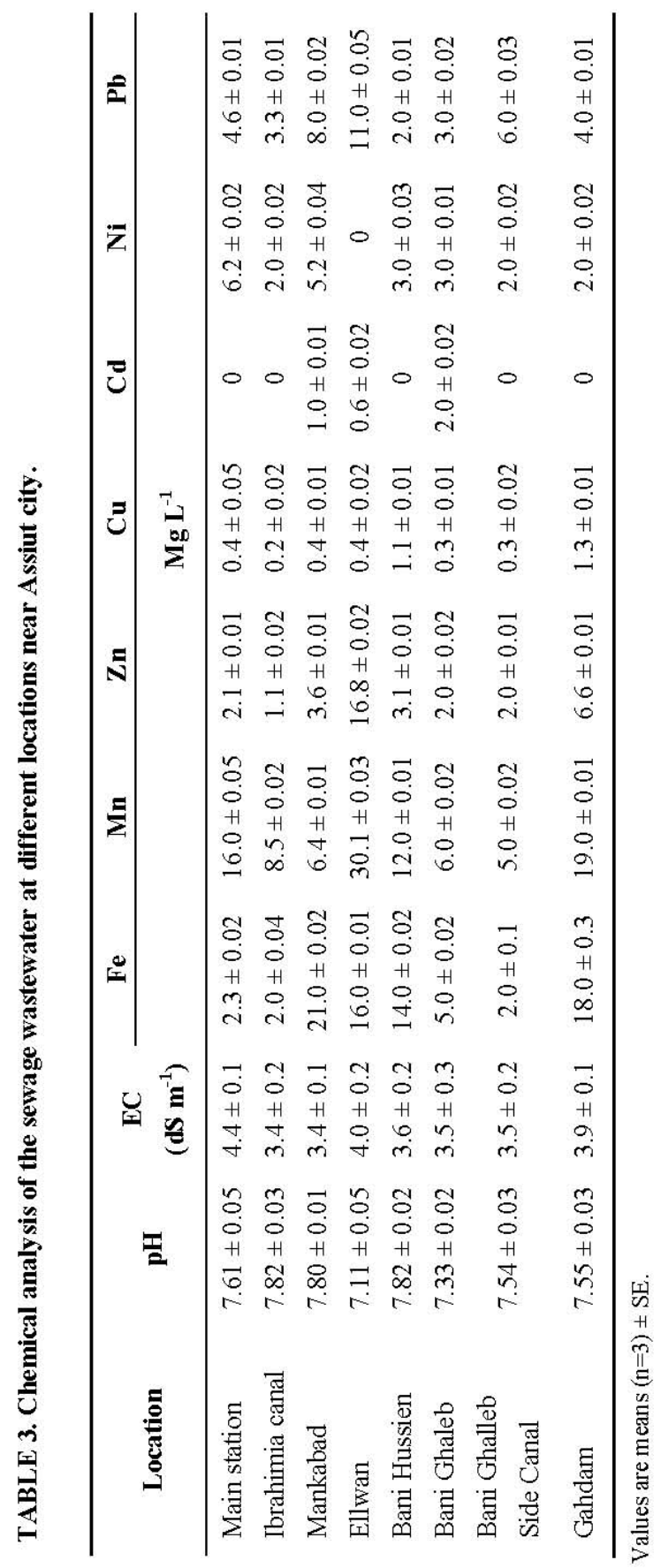

Egypt. J. Soil Sci. 54, No. 4 (2014) 

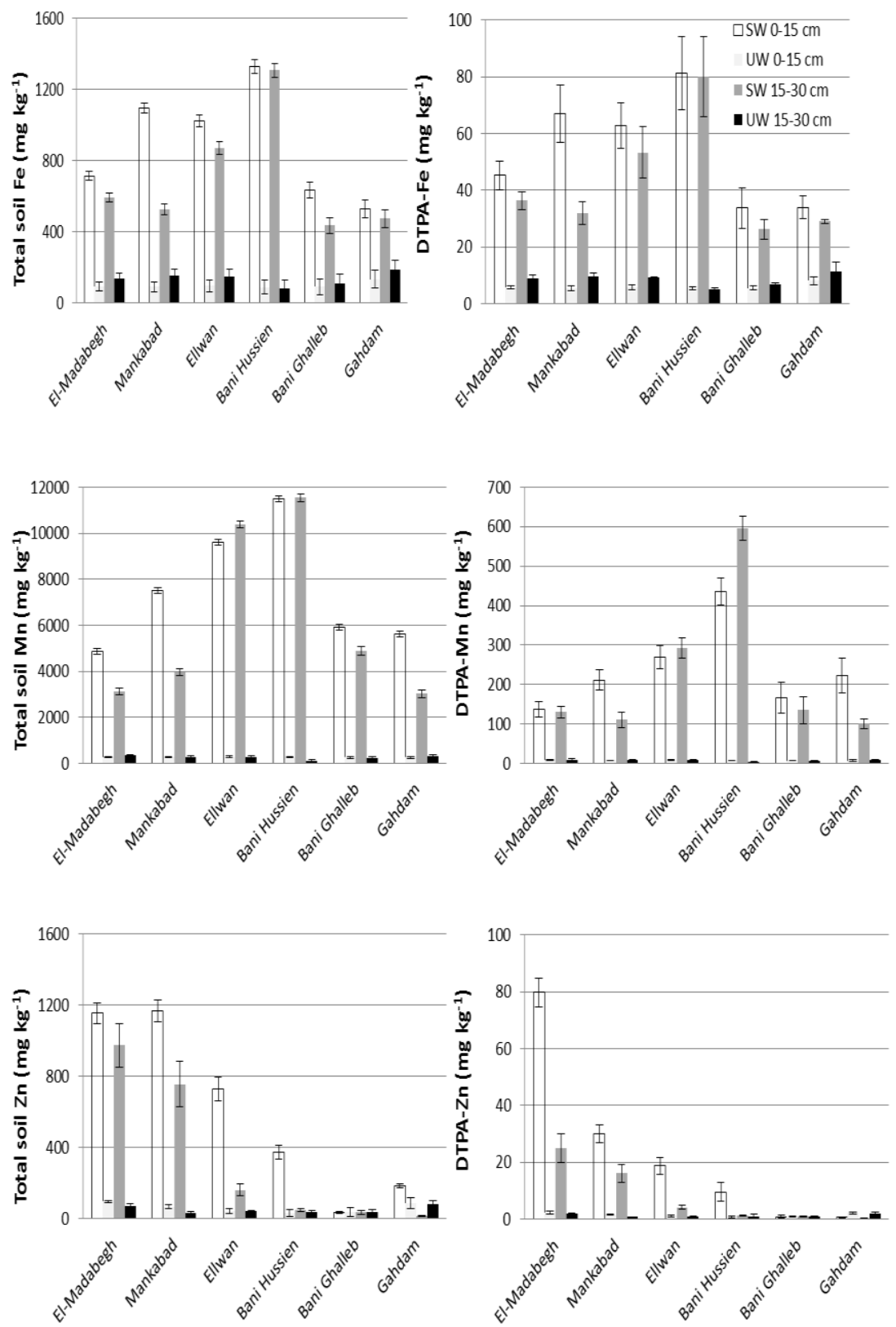

Egypt. J. Soil Sci. 54, No.4 (2014) 
A. ELGHARABLY et al.
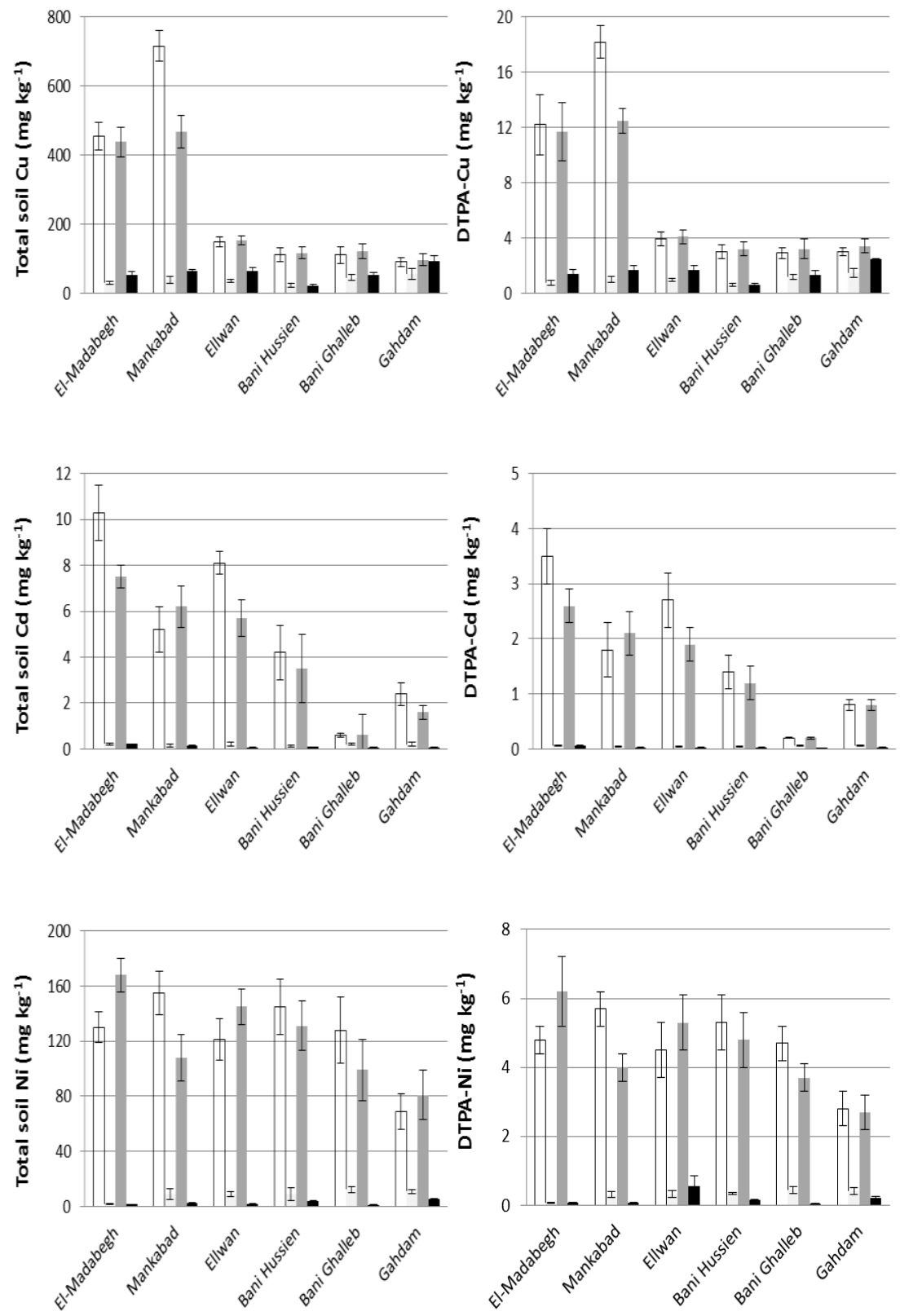

Egypt. J. Soil Sci. 54, No. 4 (2014) 

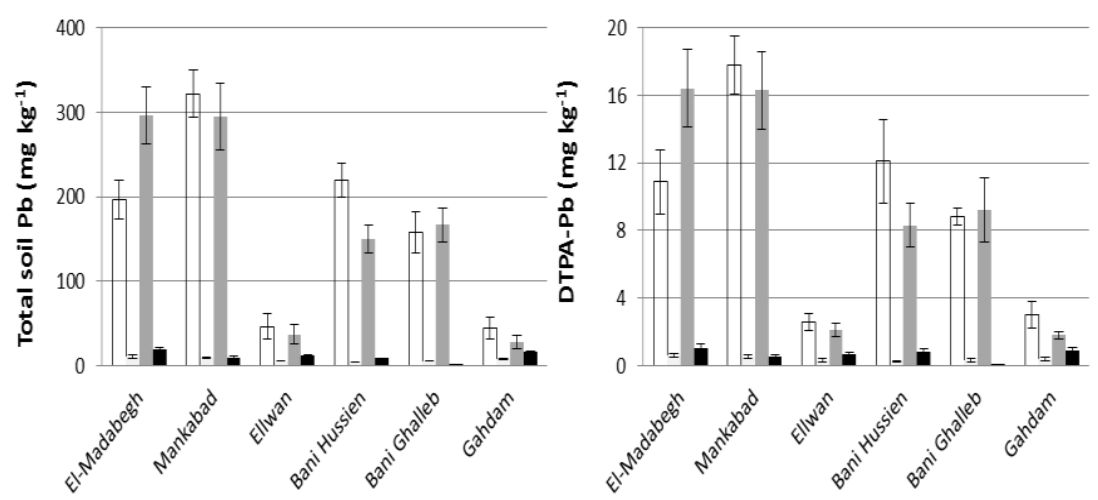

Fig. 1. Concentrations of the total and DTPA-extractable $\mathrm{Fe}, \mathrm{Mn}, \mathrm{Zn}, \mathrm{Cu}, \mathrm{Cd}, \mathrm{Ni}$ and $\mathrm{Pb}$ ( $\mathrm{mg} \mathrm{kg}^{-1}$ soil) in sewage water (SW) and underground water (UW)irrigated soils of El-Madabegh, Mankabad, Ellwan, Bani Hussein, Bani Ghalleb and Gahdam.

Comparing the above described results for the soils irrigated with sewage wastewater and those obtained for the soil irrigated with underground water in the same villages (Tables 1 and 2), data reveals marked differences due to the use of sewage wastewaters. Data reported by Shaymaa (2008) is in agreement with the data of this study.

Zinc (Zn): All soils in this study case have very high levels of total $\mathrm{Zn}$. Total $\mathrm{Zn}$ in all soil samples collected from the studied area (polluted) ranged from 115.6 to $1063.5 \mathrm{mg} \mathrm{kg}^{-1}$ soil with an average of $489.4 \mathrm{mg} \mathrm{kg}^{-1}$ soil. Concentrations of total $\mathrm{Zn}$ in the soils irrigated with sewage water were 1063.5, $962.5,444.5,210.5,135$ and $115.6 \mathrm{mg} \mathrm{kg}^{-1}$ soil in El-Madabegh, Mankabad, Ellwan, Bani Hussien, Bani Ghalleb and Gahdam, respectively. The concentration decreased from the beginning of the irrigation canal starting at ElMadabegh and ending at Gahdam along a distance of about $25 \mathrm{~km}$. This could be attributed to the possible settlement of the $\mathrm{Zn}$-containing compounds held in the sewage wastewater starting from El-Madabegh with a gradual decrease in the concentrations of these compounds along the water follow over the indicated distance. Compared to the soils irrigated with underground water, total $\mathrm{Zn}$ concentration in the soils irrigated with sewage wastewater with higher by $1268 \%$ for Madabegh, $1980.5 \%$ for Mankabad, $1036 \%$ for Ellwan, $603.5 \%$ for Bani Hussien, 367.9 for Bani Ghalleb and $141.8 \%$ for Gahdam. Data of the studies conducted by Abdel Salam (2002), Shaymaa (2008) and Nadia (2009) is in close agreement with that of this study. Data indicate that the total $\mathrm{Zn}$ concentration was higher in the surface than in the subsurface layer in the soils of the 6 locations which indicate that there was no down word movement of $\mathrm{Zn}$ in soil. 
Cupper $(\mathrm{Cu})$ : Data obtained for total $\mathrm{Cu}$ in all soil samples collected from the studied areas ranged from 93.5 to $592 \mathrm{mg} \mathrm{kg}^{-1}$ soil. Results showed higher level of total $\mathrm{Cu}$ in soils of Mankabad and El-Madabegh (592 and $241 \mathrm{mg} \mathrm{kg}^{-1}$ soil, respectively), than those of Ellwan (151 mg kg-1 soil), Bani Hyussien (114.5 mg $\mathrm{kg}^{-1}$ soil), Bani Ghalleb (116.5 mg kg-1 soil) and Gahdam (93.5 $\mathrm{mg} \mathrm{kg}^{-1}$ soil). The accumulation of total $\mathrm{Cu}$ in these soils decreased in the order: Mankabad > El-Madabegh > Ellwan > Bani Ghalleb > Bani Hussien > Gahdan.

Cadium $(C d)$ : Figure 1 shows higher concentrations of total $\mathrm{Cd}$ in soils of ElMadabegh, Mankabad and Ellwan (8.9, 5.3 and $6.4 \mathrm{mg} \mathrm{kg}^{-1}$ soil, respectively), than those of Bani Hussien (3.95 mg kg${ }^{-1}$ soil), Bani Ghalleb $\left(0.6 \mathrm{mg} \mathrm{kg}^{-1}\right.$ soil) and Gahdam $\left(2 \mathrm{mg} \mathrm{kg}^{-1}\right.$ soil). The total content of $\mathrm{Cd}$ in the surface layer ranged from 0.6 to $10.3 \mathrm{mg} \mathrm{kg}^{-1}$ soil, and it was higher than that found $\left(6.6\right.$ to $7.5 \mathrm{mg} \mathrm{kg}^{-1}$ soil) in the subsurface layer at all studied areas irrigated with sewage wastewater. In this study, the concentration of total $\mathrm{Cu}$ is higher than that $\left(0.32 \mathrm{mg} \mathrm{kg}^{-1}\right.$ soil $)$ reported by Elsokkary and Lag (1978) in the alluvial soils. Alloway (1995) reported that the common concentration of total $\mathrm{Cd}$ in agricultural soils is in the range $0.2-1.0 \mathrm{mg} \mathrm{kg}^{-1}$ soil. Therefore, the concentrations of $\mathrm{Cd}$ found in these soils were significantly higher than that acceptable for the agriculture soils (KabataPendias and Pendias, 1992, Abdel Salam, 2002 and Meers et al., 2005). The accumulation of total $\mathrm{Cd}$ in these soils decreased in the order: El-Madabegh > Ellwan > Mankabad > Bani Hussien > Gahdam > Bani Ghaleb.

Nickel (Ni): At all sites, total $\mathrm{Ni}$ in the surface layer of the soils irrigated with sewage wastewater was in the range $69-155 \mathrm{mg} \mathrm{kg}^{-1}$ soil (Fig. 1) and that in the subsurface layer was in the range $81-168 \mathrm{mg} \mathrm{kg}^{-1}$ soil. Total $\mathrm{Ni}$ in the soils of the six locations is higher than that $\left(50 \mathrm{mg} \mathrm{kg}^{-1}\right.$ soil) found in the agricultural soils (Alloway, 1995). Metwally and Rabie (1989) reported that total Ni in the alluvial and calcareous soils of Egypt ranged from 25 to 85 and from 29 to $72.2 \mathrm{mg} \mathrm{kg}^{-1}$ soil, respectively.

Lead $(\mathrm{Pb})$ : Total $\mathrm{Pb}$ in all soil samples collected from the studied areas irrigated with sewage wastewater ranged from 36 to $308.8 \mathrm{mg} \mathrm{kg}^{-1}$ soil. The surface soil layers of the various locations differed widely in their total content of $\mathrm{Pb}$. The total content of $\mathrm{Pb}$ was higher in the surface than in the subsurface layer at the studied areas, except El-Madabegh. Data indicate that the highest $\mathrm{Pb}$ concentration ( $308.5 \mathrm{mg} \mathrm{kg}^{-1}$ soil) was found the soil of Mankabad, while the lowest (36 mg kg${ }^{-1}$ soil) was recorded in soils of Gahdam. The concentration of total $\mathrm{Pb}$ found in these soils was significantly higher than those previously reported by Abdel Salam (2002). Alloway (1995) reported that a range of 10 and $30 \mathrm{mg} \mathrm{Pb} \mathrm{kg}{ }^{-1}$ soil is an acceptable concentration for agricultural soils.

It may be stated that all the soils of the six locations which were irrigated with sewage wastewater are polluted with $\mathrm{Fe}, \mathrm{Mn}, \mathrm{Zn}, \mathrm{Cu}, \mathrm{Cd}, \mathrm{Ni}$ and $\mathrm{Pb}$ due to the use of sewage wastewater over 45-50 years.

Egypt. J. Soil Sci. 54, No. 4 (2014) 
DTPA-extractable $\mathrm{Fe}, \mathrm{Mn}, \mathrm{Zn}, \mathrm{Cu}, \mathrm{Cd}$, Ni and $\mathrm{Pb}$ in soils near Assiut city

Figure 1 shows the concentration of the DTPA-extractable $\mathrm{Fe}, \mathrm{Mn}, \mathrm{Zn}, \mathrm{Cu}$, $\mathrm{Cd}, \mathrm{Ni}$ and $\mathrm{Pb}$ from soils irrigated with wastewater at El-Madabegh, Mankabad, Ellwan, Bani Hussein, Bani Ghalleb and Gahdam.

With respect to DTPA-Fe, there is a wide variation between the studied soils. Data indicate that the concentrations of the available Fe in soils of El-Madabegh, Mankabad, Ellwan, Bani Hussien, Bani Ghalleb and Gahdam were 40.8, 49.5, 58, 80.6, 29.9 and $31.5 \mathrm{mg} \mathrm{kg}^{-1}$ soil, respectively. According to Viets and Lindsay (1973), Elgharably (1993) and Elgharably (2007) soils, at the indicated sites of this study, contain high concentrations of available Fe.

Extractable- $\mathrm{Mn}, \mathrm{Zn}$ and $\mathrm{Cu}$ are varied between sampled sites. This variation was associated with variation in soil properties (Table 1). Compared to the soils irrigated with underground water at all sites, the concentrations of extractable $\mathrm{Mn}, \mathrm{Zn}$ and $\mathrm{Cu}$ of the soils irrigated with sewage wastewater were higher by approximately $3058.3 \%$ for $\mathrm{Mn}, 804.4 \%$ for $\mathrm{Zn}$ and $412.8 \%$ for $\mathrm{Cu}$. According to Viets and Lindsay (1973), all soils irrigated with sewage wastewater are polluted with $\mathrm{Mn}, \mathrm{Zn}$ and $\mathrm{Cu}$.

According to Kabata-Pendia and Pendia (1984) soils containing less than 0.01 $\mathrm{mg} \mathrm{kg}^{-1}$ soil are Cd-deficient, and those containing $0.01-0.07 \mathrm{mg} \mathrm{kg}^{-1}$ soil are Cdnon-deficient (normal range). The soils under investigation in this study contain high concentration of DTPA-extractable Cd. Highest concentration $(10.3 \mathrm{mg} \mathrm{Cd}$ $\mathrm{kg}^{-1}$ soil) of DTPA-extractable $\mathrm{Cd}$ is at El-Madabegh and the lowest $(0.6 \mathrm{mg} \mathrm{Cd}$ $\mathrm{kg}^{-1}$ soil).

Data reported by Elsokkary and Lag (1978), Shahin and Abdel Hamid (1993), Aboulroos et al. (1996) and Abdel Salam (2002) suggest that the range 1.17-1.61 mg kg $\mathrm{mg}^{-1}$ soil of extractable $\mathrm{Pb}$ could be the background concentration of $\mathrm{Pb}$ in the alluvial non-polluted soils of Egypt. Concentrations of DTPA-Pb at the studied areas in this study are higher than that reported by others and therefore these lands are considered $\mathrm{Pb}$-contaminated.

Evaluation of soil Lead, Nickel and Cadmium impact on the studied soil quality

Metals in soils exert a decisive impact on the quality of soil and its use in food production. Hakanson (1980) used the contamination factor (CF) and the degree of contamination (DC) to asses soil contamination by comparing the metal concentration of the surface layer to the metal background value. Four contamination categories were defined according to Liu et al. (2005) as follow: 


\begin{tabular}{ll}
\hline $\begin{array}{c}\text { Contamination Factor } \\
(\text { CF })\end{array}$ & $\begin{array}{c}\text { Degree of contamination } \\
\text { (DC) }\end{array}$ \\
\hline $\mathrm{CF}<1$ & Low contamination \\
$1 \leq \mathrm{CF}>3$ & Moderate contamination \\
$3 \leq \mathrm{CF}<6$ & Considerable contamination \\
$\mathrm{CF} \geq 6$ & Very high contamination
\end{tabular}

Table 4 shows the contamination factor $(\mathrm{CF})$ of $\mathrm{Pb}, \mathrm{Ni}$ and $\mathrm{Cd}$ in the surface layer of the soils irrigated with underground water (UW) and sewage wastewater (SW) at different sites near Assiut City.

Data presented show that soils at the studied sites which have been SW irrigated have values of $\mathrm{CF}$ for $\mathrm{Pb}$ in the range 6.11-50.93. At the same sites, the $\mathrm{CF}$ of $\mathrm{Ni}$ at all sites is in the range 6.33-80.75 and that of $\mathrm{Cd}$ is in the range 2.8946.82. Therefore, according to Hakanson (1980) and Liu et al. (2005) soils at all sites are considered highly contaminated with $\mathrm{Pb}, \mathrm{Ni}$ and $\mathrm{Cd}$.

Repeated application of sewage water resulted in accumulation of heavy metals in soils, reaching high levels for plants and other soil organisms. Metals that accumulate in the edible plants and pose the greatest threat to human and animal health are $\mathrm{Cd}, \mathrm{Ni}, \mathrm{Pb}, \mathrm{Cu}$ and $\mathrm{Zn}$ (Chaney, 1983). The US environmental protection agency (US EPA, 1993) regulated nine trace elements for land-applied sewage sludge. Only six of these elements $(\mathrm{Cu}, \mathrm{Ni}, \mathrm{Zn}, \mathrm{Cd}, \mathrm{Pb}$ and $\mathrm{Se})$ are considered to be phytotoxic (Schmidt, 1997).

Finally, it may be stated that all of the studied sites are considered $\mathrm{Pb}, \mathrm{Ni}$ and $\mathrm{Cd}$ contaminated due to the use of untreated sewage wastewater in irrigation of certain agricultural soils near Assiut City over 45-50 years.

\section{Conclusion}

Our study proves that the agricultural soils under investigation are contaminated with $\mathrm{Pb}, \mathrm{Cd}$ and $\mathrm{Ni}$.

The metal concentrations in soils of the studied areas exceeded the limited values recommended by several studies; however, an Egyptian standard models need to be established to be compared with for agricultural soils.

The results will serve as a pilot study for further investigation of soil and plant species in environmental pollution. We will continue this trend of investigations in our future work.

Egypt. J. Soil Sci. 54, No. 4 (2014) 


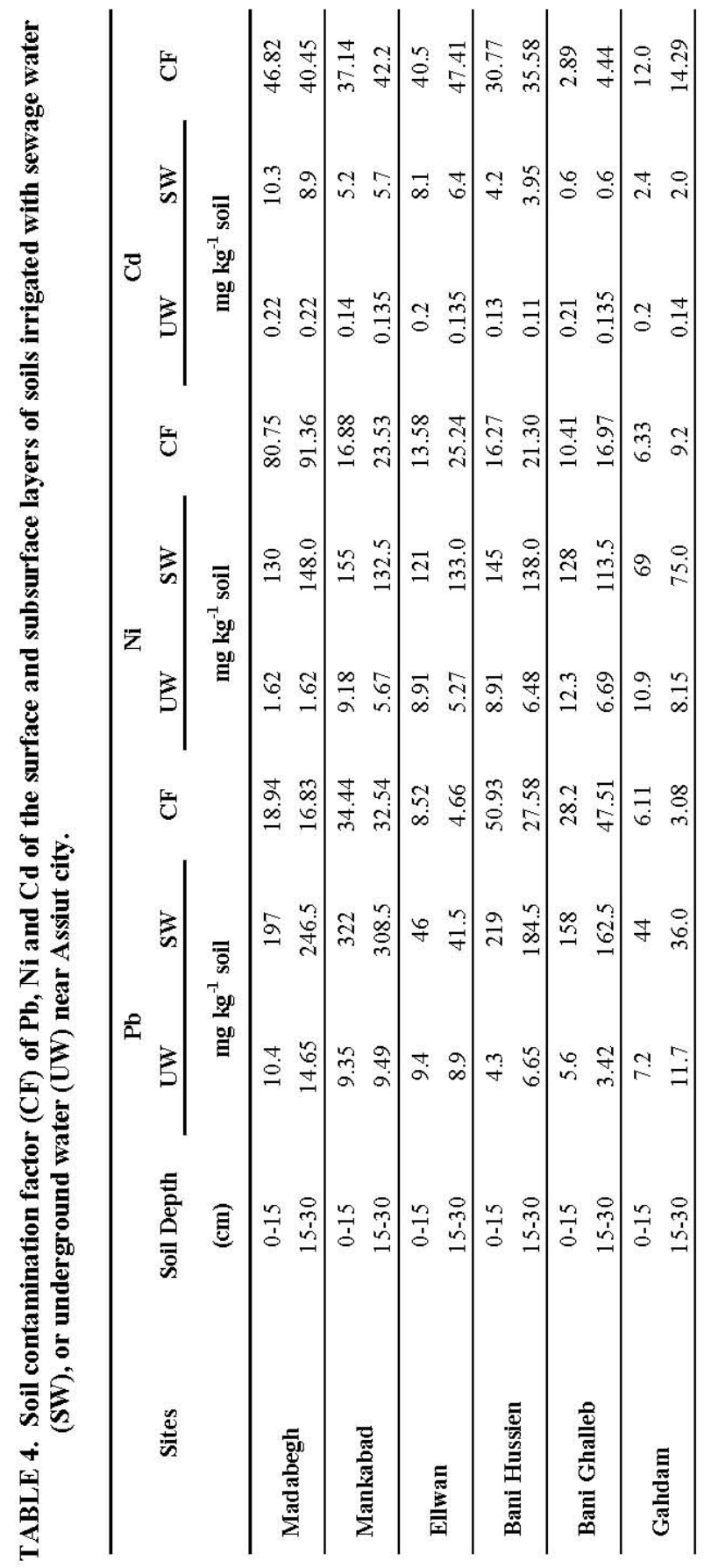

Egypt. J. Soil Sci. 54, No.4 (2014) 
Acknowledgement : This publication is an output of the research project (Heavy Metals Pollution and Remediation in Soils of Assiut, Egypt) number 2153 funded by the Science and Technology Development Fund (STDF), program of Basic and Applied Research Grants, Cairo, Egypt.

\section{References}

Abdel Salam, A.A. (2002) Distribution of heavy metals in three soil types and in corn plants at Western area of Nile delta. J. Agric. Sci. Mansoura Univ. 27: 8713-8734.

Abdel-Sabour, M.F., Ismail, A.S. and Abou Naga, H. (1996) Environmental impact of Cairo sewage effluent on El-Gabal El-Asfer farm. Egypt. J. Soil Sci. 36 (1-4): 329-342.

Aboulroos, S.A., Holah, S.H. and Badawy, S.H. (1996) Background levels of some heavy metals in soils of Egypt and associated corn plant. Egypt. J. Soil Sci. 36: 1-4.

Alloway, B.J. (1995) Heavy metals in soils. Blackie Academic and Professional, U.K.

Badawy, S.H. and Helal, M.I.D. (2002) Chemical forms and movement of heavy metals in sandy soil irrigated with sewage effluent. Egypt. J. Soil Sci. 42: 417-434.

Baker, D.E. and Amacher, M.C. (1982) Nickel copper, zinc and cadmium. In :"Methods of Soil Analysis", Vol. 2 , A.L. Page, R.H. Miller and D.R. Keeney (Ed.), pp. 323336, American Society of Agronomy, Madison.

Chaney, R.L. (1985) Potential effects of sludge-born heavy metals and toxic organics in soils, plants and animals, and related regulatory guidelines. Annex 3, workshop paper 9, pp. 1-56. The International Transportation, Utilization or desposal of sewage sludge. Pan Am. Health Organization Washington, D.C.

Chaney, R.L. (1983) Potential effect of waste constituents on the food chain. Land treatment of hazardous wastes. In :"Noyes Data Crop Park Ridge", J.F.Part, S.B. Marsh and M. Kalay (Ed.), pp. 152-210.

Chapman, H.D. and Pratt, P.F. (1978) "Methods of Analysis for Soils", Plants and Waters.

El-Demerdashe, S., Abdel-Hamid, E.A., Abed, F.M.A. and El-Kassas, H.I. (1991) Iron status and its relations to some soil variables in calcareous soils in Egypt. Egypt. J. Soil Sci. 31: 357-372.

El-Desoky, M.A. and Gameh, M.A. (1998) Heavy metals mobility and changes in properties of sandy soils irrigated with untreated sewage water at Assiut. J. Agric. Sci., Mansoura Univ. 23: 4705-4719.

Elgharably, G.A. (1993) Utilization of wastewaters for agricultural production in Upper Egypt. First Annual Report.

Elgharably, G.A. (2007) Utilization of sewage waste water in agricultural production in Upper Egypt. Case study, Water and Waste Conference, Assiut Univ., Egypt.

Egypt. J. Soil Sci. 54, No. 4 (2014) 
Elsokkary, L.H. and Lag, J. (1978) Status of some trace elements in Egyptian soils and in wheat gain. Bietrage trop. Landwinsch, Veterinarmed. 18: 35-47.

Emmerich, W.E., Lund, L.Y. and Chang, A.C. (1982) Leaching behaivourof sludgeapplied metals in two field soils. Water, Air and Soil Poll. 83: 1-20.

Hakanson, L. (1980) An ecological risk index for aquatic pollution control. A Sedimentological Approach Water Res. 14: 975-1001.

Kabata-Pendias, A. and Pendias, H. (1984) "Trace Elements in Soils and Plant", CRC Press Inc. Boca Raton. Florida, 33431.

Kabata-Pendias, A. and Pendias, C. (1992) "Trace Elements in Soils and Plants", CRC. Press. Boca Raton, FL, USA.

Lindsay, W.L. and Norvell, W.A. (1978) Development of DTPA soil test for Zn, Fe, Mn and Cu. Soil Sci. Soc. Am. J. 42: 421-428.

Liu, W.H., Zhan, J.Z., Ouyang, Z.Y., Soderlund, L. and Liu, G.H. (2005) Impacts of sewage irrigation on heavy metal distribution and contamination in Bejjing. China. Envir. International 31: 805-812.

Meers, E., Lamsal, S., Vervaeke, P., Hapgood, M., Lust, N. and Tack, F.M.G. (2005) Availability of heavy metals for uptake by salix viminalis on a moderately contaminated dredged sediment dispersal site. Environmental Pollution 137: 354-364.

Metwally, A.L. and Rabie, M.H. (1989) Nickel and Cobalt in soils of Egypt and in fodder plants. Egyptian J. of Soil Sci. 29: 275-284.

Nadia Kamal (2009) Distribution and forms of some heavy metals in a contaminated soil at Assiut. Ph.D. Thesis, Assiut Univ., Egypt.

Rattan, R.K., Datta, S.P., Chhonkar, P.K., Suribabu, K. and Singh, A.K. (2005) Longterm impact of irrigation with sewage effluents on heavy metal content in soils, crops and ground water-a case study. Agric., Ecosystems and Environment 109: 310-322.

Schmidt, J.P. (1997) Understanding phytotoxicity thresholds for trace elements in landapplied sewage sludge. J. Environ. Qual. 26: 4-10.

Shahin, R.R. and Abdel Hamid, M.A. (1993) Speciation of selected heavy metals in some soils of Egypt. Egypt. J. Soil Sci. 33: 305-327.

Shaymaa, M.K. (2008) Extractability and availability of some nutrients in contaminated soils of Assiut. M.Sc., Assiut Univ., Egypt.

Sterritt, R.M. and Lester, J.N. (1980) Analysis of leaching behaviour of sludge-applied metals in two field soils. Water, Air and Soil Poll. 83: 1-20.

Yadav, R.K., Goyal, B., Sharma, R.K., Dukey, S.K. and Minhas, P.S. (2002) Postirrigation impact of domestic sewage effluent composition of soils. Crops and ground water - a case study. Environment Int. 28: 481-486. 
Viets, F.G. and Lindsay, W.L. (1973) Testing soils for $\mathrm{Zn}, \mathrm{Cu}, \mathrm{Mn}$ and $\mathrm{Fe}$. In : "Soil Testing and Plant Analysis", L.M. Walsh and J.D. Beaton (Ed.), pp. 153- 172, Soil Sci. Sec. Am. Inc. Madison, WL, USA.

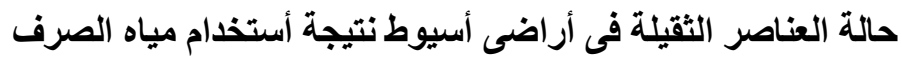

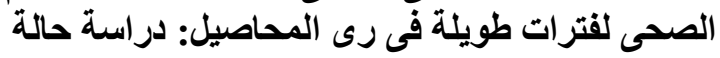

$$
\begin{aligned}
& \text { أحمد الغرابلى" ، عاصم عبد المجيد"* و جلال الغرابلى" الزئ }
\end{aligned}
$$

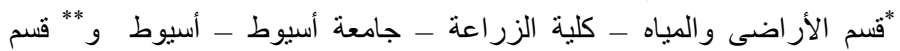

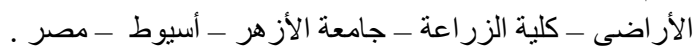

$$
\begin{aligned}
& \text { تهذف هذه الدراسة الى تقييم حالة عناصر الرصاص و النيكل و الكادميوم و الحديد }
\end{aligned}
$$

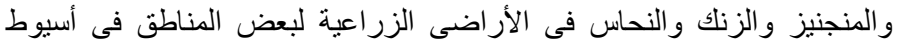

$$
\begin{aligned}
& \text { و التى يتم ريها باستخدام مياه الصرف الصئ الصحى منذ ما يقرب من } 40 \text { - } 50 \text { عام. فئ. }
\end{aligned}
$$

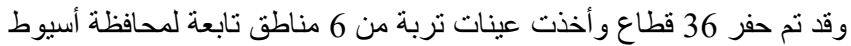

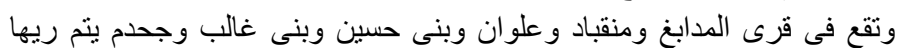

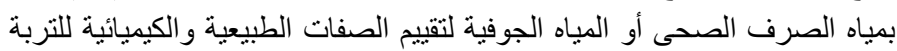

$$
\begin{aligned}
& \text { وتقدير التركيز الميسر والكلى للعناصر المذكورة. كما تم أخذ عينات من الماء المياء } \\
& \text { المستخدم فى رى المحاصيل المختلفة فى كل منطقة. } \\
& \text { ومن النتائج المتحصل عليها أتضح أنه مقارنة للأراضى المروية بالمياه }
\end{aligned}
$$

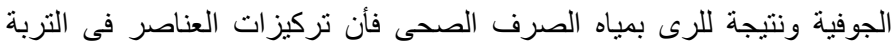

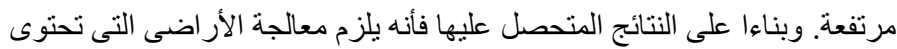

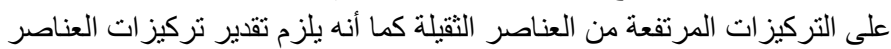

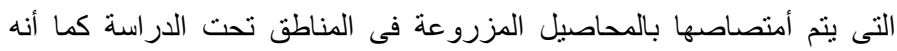

$$
\begin{aligned}
& \text { يوصى بجدولة أستخدام مياه الصرف الصحى فى الرى فى هذه المناطق. }
\end{aligned}
$$

